\title{
Etherealization in a Racial Regime of Ownership: Marconi in O'ahu, circa 1900
}

\author{
Tyler Morgenstern ${ }^{\text {a }}$ \\ Keywords: settler colonialism, property, hawai'i, marconi, wireless, media history \\ https://doi.org/10.1525/001c.23515
}

\begin{abstract}
This article traces the emergence of wireless telegraphy in the Hawaiian Islands in the late nineteenth and early twentieth centuries. Centrally, I argue that for an ascendant haole (white settler) planter class, wirelessness proffered potent resources with which to articulate a particular model of scale and connectivity-one in which Hawai'i's isolation from the US mainland was recast as the predicate of new, and highly lucrative, forms of intimacy and proximity. These intimacies, I argue, overlapped not just symbolically but materially with the de facto and de jure forms of US colonial governance that took shape in the islands in this period. To make the case, I think through and around one particularly notable wireless transmission complex: the American Marconi Company's hulking installation at Kahuku, on the North Shore of O'ahu, and its companion station at Koko Head, some fifty miles south. Recounting the maneuvers by which these sites were drawn into the fold of long-distance wireless signaling, I show that to whatever extent wirelessness animated transcendent visions of scalar extensibility and global connectivity, it did so from within the confines of a colonial economy of land use, elaborated around the enclosure and privatization of Indigenous land and the racially stratified exploitation of migrant labor. By way of conclusion, however, the article also considers how Kānaka Maoli (Indigenous Hawaiians) are today developing new models of wireless connectivity that upend this history of colonial enclosure by articulating wirelessness to projects of Indigenous nation building.
\end{abstract}

\section{Marconi Farms}

Regrettably, it is my final day on the island of $\mathrm{O}^{\prime}$ ahu, where I have spent much of the last two weeks holed up at the University of Hawai'i at Mānoa, conducting research for a dissertation chapter focused on the ALOHAnet, an experimental wireless computer network developed at UHM in the late 1960s. To mark the occasion, I embark on a small sojourn along the island's famed North Shore, globally renowned for its stunning coastal vistas and ideal surf conditions. From my small flat in the town of Haleiwa, I wind my way north along the Kamehameha Highway, eventually reaching the immaculately manicured grounds of the Turtle Bay resort area, which sits perched atop a rocky promontory between Kulima Cove to the north and Kawela Bay to the south. Hoping to find a quiet spot from which to enjoy the scenery, I leave my vehicle in one of the area's many parking lagoons and duck into the lobby of the property's central hotel. A notification on my smartphone alerts me that the lobby's Wi-Fi network is unprotected, so I take the opportunity to catch

\footnotetext{
a Tyler Morgenstern is a PhD Candidate in the Department of Film and Media Studies at UC Santa Barbara. His research focuses broadly on the development, design and use of information and communication technologies-wireless ICTs, in particular -in colonial contexts. With Ian Alan Paul and Krista Lynes, he is co-editor of Moving Images: Mediating Migration as Crisis (Transcript Verlag, 2020), and with Xiuhe Zhang, co-editor of Issue 15 of Media Fields Journal, "Media Cultures of the Imperial Pacific." His writing has also appeared in International Journal of Communication, Synoptique, and The Conversation.
} 


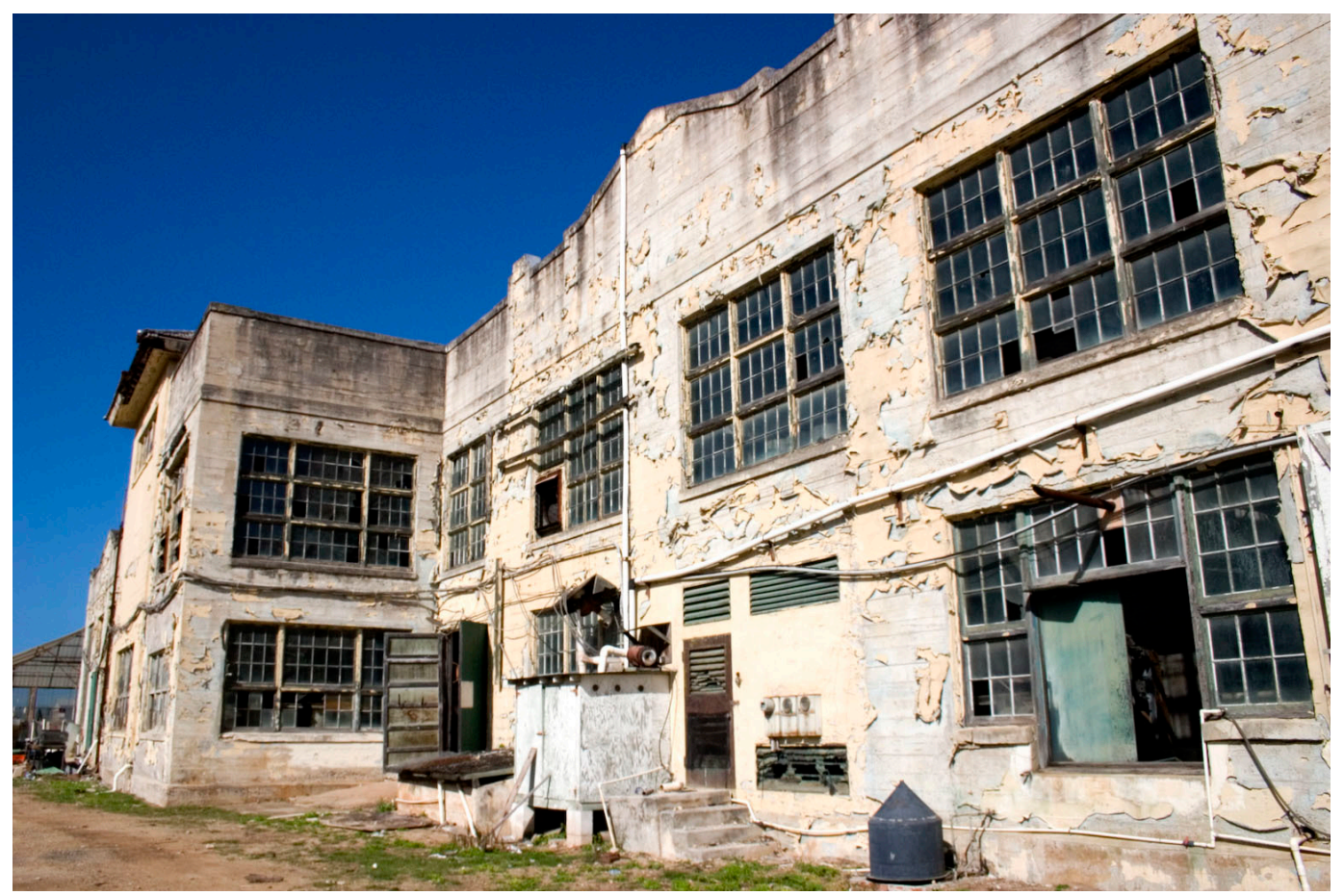

Figure 1.1: Remnants of Marconi facility at Kahuku: views of operational building facade.

Image: Jonathan Haeber, Flickr, Creative Commons Attribution License.

up with a few of the emails accumulating in my in-box. As always, the task proves less than thrilling, and soon I am fiddling distractedly with my preferred navigation app. A moment later, an unthinking swipe of the finger reveals something peculiar: about a mile up the freeway, in an area known as Kahuku, is a site marked "Marconi Point."

In a sense, this should come as little surprise. In the course of my ALOHAnet research, it has become clear that the figure of Guglielmo Marconi looms large in the history of Hawaiian information communication technology (ICT) development. Even so, seeing the wireless pioneer's name scrawled so clearly on the landscape catches me off guard. A quick search into the history of the site only compounds my surprise. Not only was Kahuku home to one of the many Marconi wireless installations that proliferated across the islands in the early years of the twentieth century; for a brief time in the teens, it also played host to the largest and most powerful Marconi station on the planet. Intrigued, I resolve to visit the site. This proves unexpectedly difficult, however. The site's access road is so sparingly marked that I initially breeze right past it. After a few more failed passes, I succeed in locating the entryway, which opens onto a trail cut into a dense thicket of dry brush. Driving along the winding trail, I eventually come upon a handful of construction workers clad in high-visibility vests. Correctly surmising that I am a lost tourist, one of the workers approaches my vehicle; I roll down the window to ask him whether I am at Marconi Point, and whether I might take a few photos of the old wireless campus, the crumbling remnants of which rise from the dust about a hundred yards seaward. 


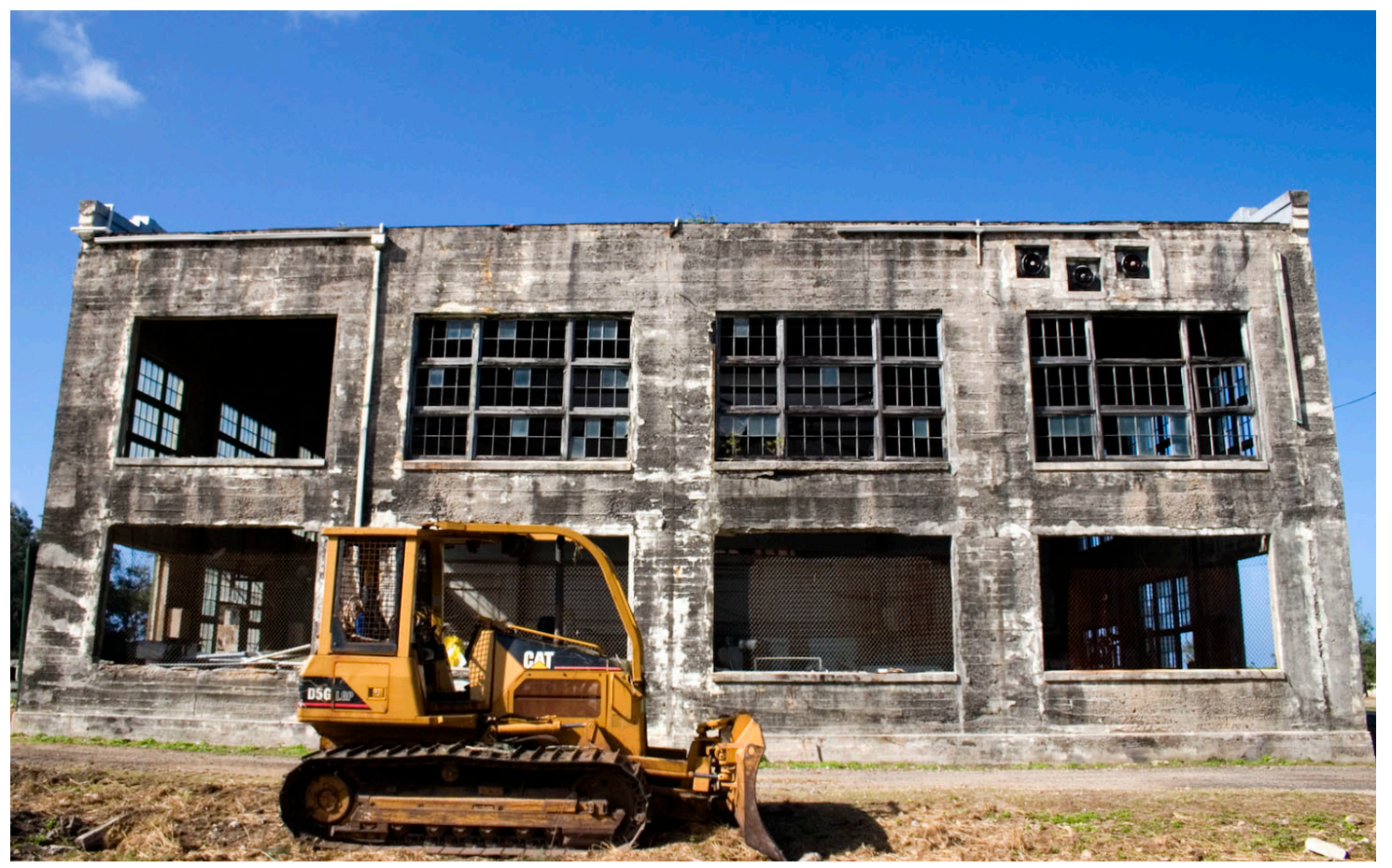

Figure 1.2: Remnants of Marconi facility at Kahuku: views of operational building facade.

Image: Jonathan Haeber, Flickr, Creative Commons Attribution License.

Friendly but circumspect, he points me farther up the trail. Soon, the dusty path gives way to a freshly paved ribbon of asphalt and the brush falls away on all sides, revealing a precisely graded clearing dotted with utility boxes. Clearly, I have stumbled into not a heritage facility but the early stages of a housing development that a sign to my left tells me is to be called Marconi Farms. ${ }^{1}$

Some weeks later, back on the mainland, I find myself reflecting on my brief, fumbling visit to Kahuku, considering what it might mean to have found housing plots where I had expected to find the traces of media history, and what (beyond the vagaries of branding) might be bound up in the bizarre toponym Marconi Farms. What might be at stake, I wonder, when the technics of wireless communication are discursively adjoined to the territorializing practices of industrial agriculture, the economic maneuvers of real estate development, and the legal apparatus of property that subtends both? In this article, I attempt to give this question its due. Building on recent efforts to account for how the unfinished histories of colonialism and empire striate, and in many respects underpin, the interface of "media" and "environment" (Walker 2018; Tully 2009; Starosielski 2012; Smithies 2008; Greaves 2018), in what follows, I consider what the Kahuku site might reveal about the historical entanglements between ICT development, settler agribusiness, and the colonial politics of land use in the Hawaiian Islands. Moreover, I wish to 
show how these entanglements continue to inform how specific constituencies negotiate the politics of communication and connectivity across the archipelago, paying particular mind to how Hawaiian sovereignty activists have in recent years transformed the task of wireless ICT development into a means of contesting the material structures and political logics of colonial proprietorship - of designing and enacting alternative territorial imaginaries that unsettle those histories of dispossession, enclosure, and exploitation out of which Marconi Farms was born.

To do so, I trace the discursive construction of wireless communication in the English-language haole (white settler) press in the latter years of the nineteenth century, showing how Hertzian wave telegraphy in general and the Marconi system in particular helped to energize potent fantasies of scalar extensibility and global connectivity among the archipelago's politically ascendant planter class. Deeply invested in cultivating more robust economic ties between the archipelago and the US mainland, the haole planter class, as I will show, greeted the wireless with great enthusiasm, seeing it as a ready-to-hand means of flouting geographic constraint and collapsing the vastness of oceanic space into lucrative new arrangements of intimacy and proximity. In keeping with the concerns of this stream of Media+Environment, I understand this imaginary as a model of scale and connectivity; not as so much airy speculation, but rather a pitted conceptual project that sought to arrange in particular ways-and to particular ends-the relations between the global and the local, the distant and the proximate. Indeed, though this model often trafficked in familiar tropes of transcendence and sublimity, treating the disappearance of wires as tantamount to the disappearance of material constraint, I want to argue that what it put at stake was nothing less than a new configuration of the material world-a novel way of mapping and ultimately governing the relations between the Hawaiian Islands, the US mainland, and the wider Pacific.

To this end, I follow Ghislain Thibault (2014) in understanding this model as a scene of etherealization. Writing specifically of Nikola Tesla's ill-fated efforts to develop a method for the wireless transmission of electric power, and drawing as well on the work of British historian Arnold Toynbee, Thibault suggests that something more than technical simplification is at hand when wired methods of transmission are supplanted by their wireless counterparts. As Thibault writes, "While the webs of wires of telegraph and telephone exchanges could be explained with an analogy that had an equivalent in the natural world-the human nervous system - the etherealized telegraphy challenged any existing models about the living world" (91). By stretching established imaginaries of space and scale in peculiar new directions, the wireless not only "reorganized both the science and the industry of electrical engineering, and opened up the commercial practices that would become the broadcasting industry," it also "unsettle[d] preexisting conceptions about physical reality and uplifted metaphysical claims in the popular and scientific discourse" (92). 
But if etherealization helps to reframe wireless ICTs like the Marconi system less as the harbingers of a dematerialized mode of communication and more as the predicates of a peculiar new genre or mode of materiality, it also begs the question of in what, exactly, this new materiality consists. What specific configurations of labor, capital, land, and technology subtend (or follow from) the decision to eschew terrestrial cables in favor of electromagnetic radiation? In what follows, I hazard a response. By reconstructing the institutional and political conditions under which first British then American Marconi's brief sallies with $\mathrm{O}^{\prime}$ ahu took shape, I argue that in the Hawaiian context, the process of etherealization was bound up in consequential ways with those emphatically material practices of territorial enclosure, labor discipline, and resource extraction immanent to the colonial situation. More specifically, I suggest that wirelessness in Hawai'i emerged co-constitutively with what Brenna Bhandar (2018), adapting the work of Cheryl Harris, Stuart Hall, and Cedric J. Robinson, has called a racial regime of ownership. Though I will unpack this term at greater length below, briefly, it can be understood as a jurisprudential and administrative formation in which the dismemberment of Indigenous land tenure regimes comes to be constitutively bound to the production, governance, and exploitation of modern racial subjects through the legal apparatus of property. Differently instantiated in different parts of the colonized world, the "disciplinary power" of these regimes generally consists in "organizing territory and producing racial subjects through a hierarchy of value constituted across the domains of culture, science and economy" (Bhandar 2018, 2). Ensconced within a rapidly expanding economy of real property founded on the sweeping dispossession of Kānaka Maoli (Indigenous Hawaiian) commoners at midcentury, dependent on a thoroughly racialized system of labor exploitation innovated within the colonial plantation economy, and promoted with great vigor by a commercial press very much in the pocket of the haole planter class, the hulking wireless station that rose at Kahuku, I argue, was deeply embedded within just such a "hierarchy of value," at once symptomatic and (re)productive of a specific configuration of settler-colonial rule.

Making the case will require some creative methodological maneuvering. Though launched to great fanfare, Marconi's Hawaiian enterprise was, as we will see, remarkably short-lived. As a result, the project's archival shadow is surprisingly small, limited to a single box of financial records, legal documents, and correspondence between key Marconi companymen such as Andrew Gray and Hawai i-based engineers such as F. J. Cross, whose professional itineraries I will trace in detail below. Thus while my argument will make some use of official Marconi Company records, it will also (as suggested above) depend to a large extent on accounts of the enterprise published in the English-language 
press. ${ }^{2}$ It goes almost without saying that these are by no means neutral or disinterested documents. On the contrary, as historians such as Helen Geracimos Chapin (1996) and Noenoe Silva and Iokepa Badis (2008) have shown, since at least the 1830s, newspapers have been central to the negotiation of social, political, and intellectual life in the Hawaiian Islands, offering opportunities for Kānaka Maoli to forge a vibrant culture of public deliberation even as they often served as bullhorns for the interests of a haole planter class broadly committed to the twin causes of cash-crop agriculture and US annexation. Indeed, as Geracimos Chapin (1996) demonstrates, within two decades of print's introduction to the archipelago, no fewer than four distinct classes of newspaper had emerged: establishment and "oligarchy" papers that promulgated the interests of a predominantly haole industrial and economic elite (3); opposition papers, including Hawaiian nationalist outlets and the ethnic and labor press; official papers, formal organs of the state that served mainly to promote the policies of the government and its allies; and independent papers, not clearly aligned with any particular population or set of political interests. To these categories, Silva and Badis (2008) add a fifth: Hawaiian-language papers that, while associated with and published by haole missionaries, nonetheless played a key role in the development of a specifically Kanaka Maoli public sphere beginning in the 1830s.

My analysis will draw primarily on the first of these categories. "Republican in politics and capitalist and expansionist in conviction," establishment-oligarchy papers like the Daily Bulletin, its offspring the Honolulu Star-Bulletin, and the Pacific Commercial Advertiser were generally unsparing in their criticism of the Hawaiian government, and they routinely threw their weight behind causes that their haole editors believed would expedite the cause of US annexation (Geracimos Chapin 1996, 3). Among these were "free-trade" agreements like the 1875 Treaty of Reciprocity, which granted US commercial interests near exclusive access to and control over the Hawaiian sugar market, and the development of robust telecommunication systems, which many members of the planter class saw both as vital tools for growing the increasingly global trade in Hawaiian sugar, and as essential bulwarks against British and German imperial designs on the mid- and Asia-Pacific. In what follows, these materials play an important role in filling the many evidentiary gaps that punctuate the Marconi archive. All the same, I do not understand them as simple records of fact. Rather, in recounting the rise and fall of the Hawaiian Marconi system through the annals of the establishment press, I mean precisely to highlight how material investments in colonial proprietorship and its adjoining

\footnotetext{
2 Due to travel and document reproduction restrictions related to the ongoing COVID-19 pandemic, I have thus far been unable to consult the Marconi papers, held at the Bodleian Libraries at Oxford University, in person. In crafting this argument, I have thus relied heavily on transcripts of these records provided by Dr. Marc Raboy of McGill University, whose remarkable book, Marconi: The Man Who Networked the World, has been foundational to my understanding of the history of wireless in the Hawaiian Islands and beyond. I am extremely grateful to Dr. Raboy for his generosity. Without his intervention and support, this article would have been altogether unfinishable.
} 


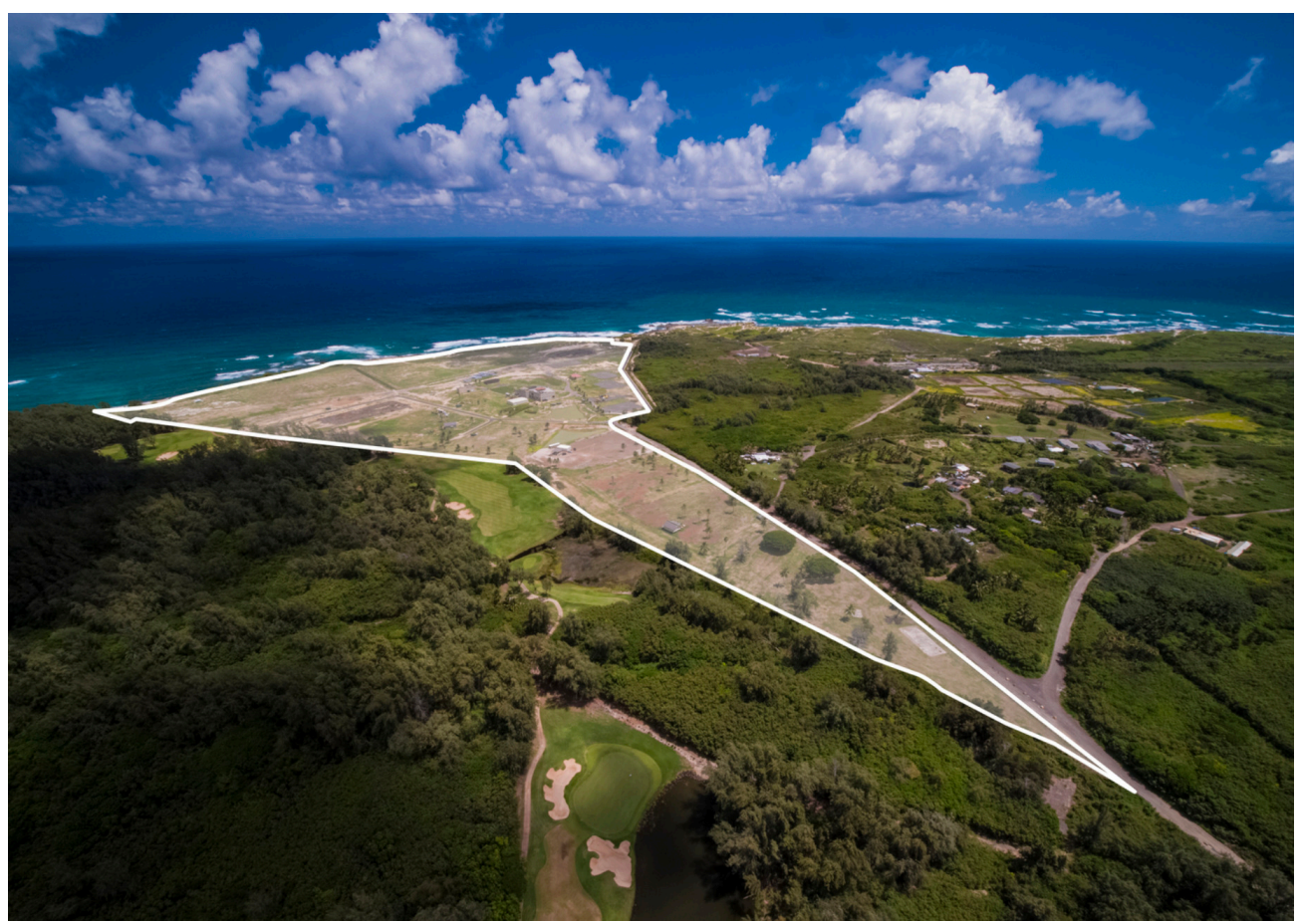

Figure 2.1: Promotional images of Marconi Farms housing development, Kahuku, O`ahu, Hawai'i.

Author's screen captures.

techniques of racial governance underwrote the vertiginous fantasies of transcendence and connectivity that accrued to wireless signaling on the cusp of annexation, as well as in its immediate aftermath.

\section{Highly Favored: Hawai'i, Wireless, and the Electrical Sublime}

It began with a bang. On September 24, 1914, before a crowd of some two hundred prominent businessmen and legislators, Lucius Eugene Pinkham - the Massachusetts-born industrialist who less than a year prior had been appointed governor of the territory of Hawai' $i$ by US president Woodrow Wilson-depressed a silver telegraph key placed ceremoniously at the head of an outdoor banquet table. "With that movement," reported the Honolulu Star-Bulletin the following morning, "the Marconi wireless plant on Oahu was formally opened and trans-pacific communication by the new system successfully established" (Honolulu Star-Bulletin 1914b, 1). What followed, though, was not the gentle tapping or quiet beeping one typically associates with telegraphic communication. Rather, at Pinkham's cue, the facility, which rose imposingly from the earth at Kahuku, a productive agricultural district on the island's North Shore, sprang to life with a roar. By the Star-Bulletin's account, "The crash of the wireless spark drowned all other noises in the plant and for a moment stilled the big crowd of guests" (Honolulu Star-Bulletin 1914b, 1).

The clamor offered audible confirmation that the "huge concrete powerhouse" (Hawaiian Gazette 1914, 2) was indeed a hulking, formidable thing. With a note of awe palpable even in print, the Hawaiian Gazette-a paper that, 


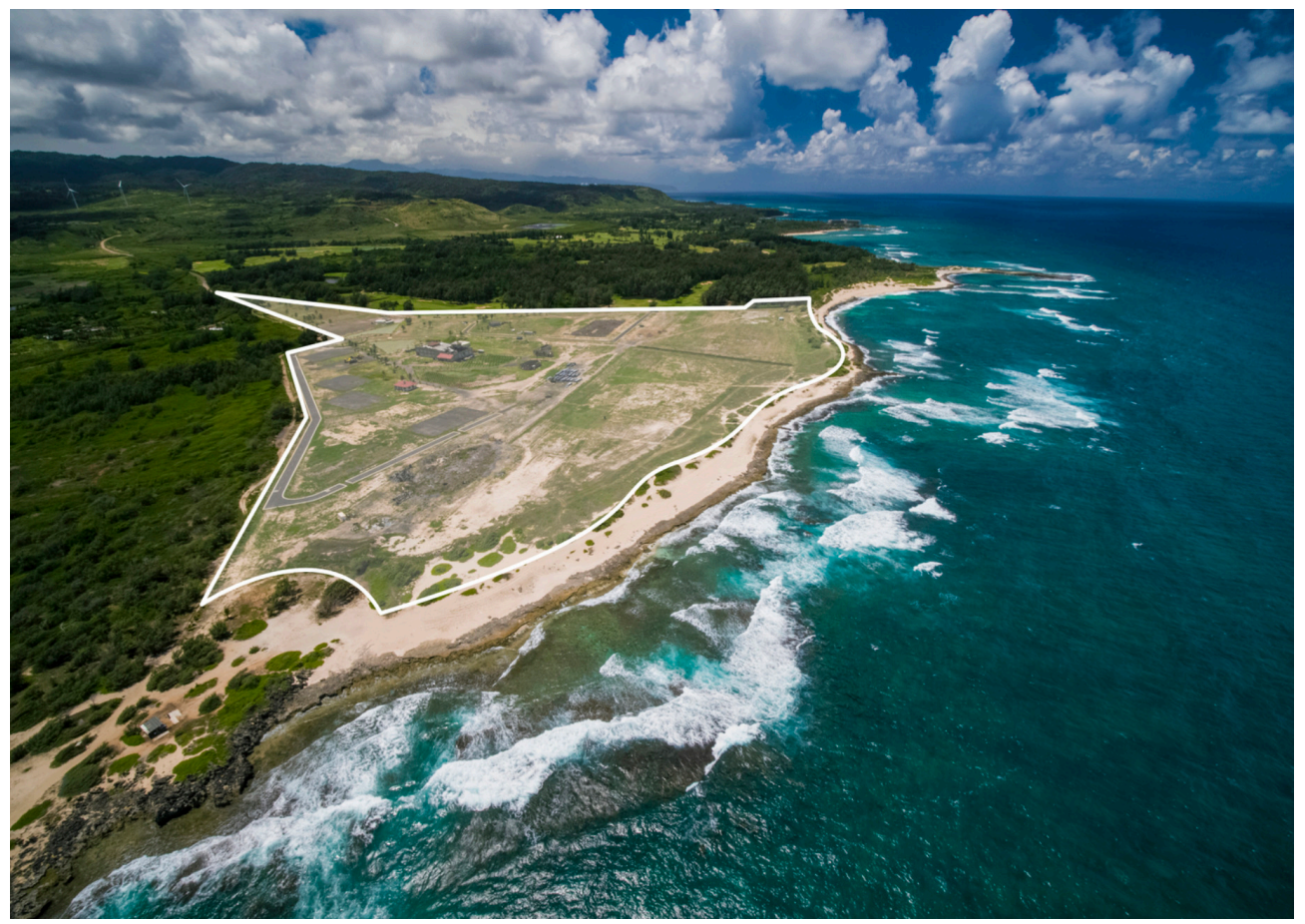

Figure 2.2: Promotional images of Marconi Farms housing development, Kahuku, O‘ahu, Hawai'i.

Author's screen captures.

despite having at one point served as an official organ of the Hawaiian government, had in the latter years of the nineteenth century become a vocal mouthpiece for the haole planter class-underscored the enormous scale of the operation:

With its bewildering mass of machinery, its hundreds of mysterious glass tanks, its "spark room," in which a few of the venturesome stepped with ears carefully stopped with fingertips, and its gleaming red "Danger" signs on the walls, [the plant] was an eye-opener. The very substantial boarding house, two stories of concrete, the administration building and the other concrete structures, set down amid great towering steel masts, covering the country for a mile, with wires, wires, wires running in every direction, all were as impressive as they were surprising, and this surprise was multiplied when it was explained that the Kahuku station was only half of the plant ready for operation by the company on Oahu. (Hawaiian Gazette 1914, 2)

This last detail was no exaggeration. Some fifty miles south, connected to the Kahuku plant by overland wire, was a second behemoth installation at Koko Head. Here, "five masts, each 320 feet high and 1000 feet apart," rose from the ground, comprising a receiving array intended to capture transmissions incoming from San Francisco (Honolulu Star-Bulletin 1913, 16). The station also boasted "six other masts, each 450 feet high...for carrying the Yokohama aerial" (Honolulu Star-Bulletin 1913, 16). What's more, the facility was 
outfitted with a cutting-edge multiplexing system that purportedly allowed it to process two incoming and two outgoing messages at a time, "with absolutely no interference" (Honolulu Star-Bulletin 1913, 16). For the Star-Bulletin, these achievements were nothing short of epoch making. "The completion of the Marconi station here...will mark the beginning of a new era in wireless communication between the Hawaiian Islands and the outside world.” Hawai' $\mathrm{i}$, the report continued, enraptured,

has been favored with being selected as the site for the largest wireless station in the world. While situated in the middle of the Pacific ocean, isolated, as it were, from the rest of the world except for a single cable and a wireless station only capable of working at night, Hawaii will be able to throw off this isolation with the coming of the Marconi system, get into a more complete touch with the rest of the world, and be drawn into closer relations with the country of which it is a territory. (Honolulu Star-Bulletin 1913, 16)

How had all this sound and fury come to pass? How had Hawai'i, a site by many measures marginal to established geographies of industrial and technological power, attained such a favored position within the burgeoning field of long-distance wireless communication? Though Guglielmo Marconi's celebrity status was by this point well established, his towering reputation had yet to translate into financial stability for his Wireless Telegraph and Signal Company (WTSC), headquartered in London. Embroiled in an expensive and seemingly endless stream of patent lawsuits on both sides of the Atlantic and facing intense criticism from many national governments regarding its unabashedly monopolistic business practices, the company's startling technical achievements in these years did little to bolster its fiscal outlook (Winseck and Pike 2007; Raboy 2016). To make matters worse, the Marconi name had been badly tarnished by the company's unseemly involvement in the Second Boer War (1899-1902), as well as by its founder's extremely public friendship with King Leopold II of Belgium, whose atrocities in the Congo Free State were by this point well-known in Europe and the subject of much scorn among liberally minded reformers (Winseck and Pike 2007; Raboy 2016). Why, in a moment of such acute uncertainty, would the company have felt it wise to spend a million dollars on an "isolated" archipelago in the middle of the world's largest ocean?

As Raboy (2016) suggests, rather than serving as deterrents, these circumstances in fact led Marconi-a shrewd strategist where matters of branding, (self-) promotion, and public perception were concerned-to regard the Hawaiian Islands as something of a test case, as well as a much-needed opportunity to refurbish the company's public image. What better way to quiet the critics and detractors than to draw this most remote of locales into the fold of global connectivity? How better to make the case for the beneficence 
of corporate monopoly than to transform what was to many contemporary observers an industrial backwater into the beating heart of an emerging global communications apparatus-a sprawling network of radiant nodes and ethereal edges that, when complete, would make it possible for people on "opposite ends of the earth to speak as if together in the same room" (Badino and Navarro 2018, 6)? With Hawai' $i$ in hand, the WTSC would be uniquely poised to align itself with the technocultural imaginary that James Carey (1988) has called the "electrical sublime" (206). A basically "religious" disposition, the electrical sublime linked modern communication technologies like the telegraph with deeply held cultural investments in such humanistic values as harmony, peaceable relation, and global brotherhood (Carey 1988). By collapsing geographic distance into ever more minute fragments of time, such technologies held forth the promise of a more integrated and proximate world-of relation, connection, and intimacy unencumbered by the constraints of physical space, national borders, and linguistic difference alike.

Ironically, however, as the nineteenth century drew to a close and the pace of telegraphic development quickened on a global scale, wired communication infrastructures increasingly came to be seen as physical encumbrances that in fact "threatened mobility in both urban and domestic spaces" (Thibault 2014, 88). This was especially true in major urban centers like New York and London, where dense thickets of overhead wire and unseemly aboveground utility poles stirred potent fears of death by electrocution and "impeded people's ability to circulate freely in public spaces" (89). As a result, by the time a young Marconi had begun his foundational experiments in wireless transmission at Villa Griffone, near Bologna (ca. 1894-95), the dream of electrical sublimity was already in search of a new infrastructural host, one capable of reconciling the connective affordances of telegraphy with a growing desire to do away with "the forests of masts and net-work of iron wires" that increasingly choked the urban landscape (89). Though still rather poorly understood by scientists and lay publics alike, Hertzian wave signaling fit the brief exactly. If wired telegraphy, as Carey (1988) argues, had begun the task of dematerializing communication by severing it from the pragmatics of transportation, the wireless went one dramatic step further, jettisoning altogether the need of a terrestrial infrastructure. In the latter's place, the wireless would leverage the ether, that most "subtle and imponderable" of media, which since antiquity had been "a source of speculation among scientists and philosophers alike" (Thibault 2014, 91). A universal yet unseen "field of emanations," the ether was thought to fill the spaces between all things, connecting precisely by means of absolute transcendence (Milutis 2006, xi). Amid the fractious upheavals of industrial modernity, this vision of the world as of a piece with itself-suffused with a continuous energetic substance floating weightlessly overhead-revived such "cherished" humanistic values as "stability, intelligibility, and common sense" (Badino and Navarro 2018, 6). 
Tangled in scandal and up against the financial and regulatory ropes, Marconi, by the late 1890s, was keen to find some way of stamping these values with his own name, of identifying his Wireless Telegraph and Signal Company with the sublime dream of peaceable interconnection on a global scale. The Hawaiian Islands offered a unique opportunity to do just that. As Marc Raboy (2016) writes, "Marconi's international prestige was now at stake-Hawaii was more than just another location; it was remote and exotic and if wireless could be useful there it would succeed anywhere" (133). It comes as little surprise, then, that in correspondence with F. J. Cross-the engineer who in 1899 would negotiate a contract for the provision of a Marconi wireless system in the Hawaiian Islands-Marconi engineer Andrew Gray (1900a) would strike an emphatic chord: "I am as anxious as yourself that this commercial wireless should be a success...from Marconi's point of view the system must work."

\section{Making Scale in and through Property Law}

But whereas for Marconi and his ilk, Hawai'i's "marginal" position within global distributions of industrial and political authority was something of a strategic boon, for the haole planter class, it was a source of much anxiety, representing a clear threat to their ongoing efforts to enshrine white minority rule and US political hegemony across the archipelago. After all, when the Marconi facilities at Kahuku and Koko Head were brought online in the fall of 1914, the territory of Hawai' $i$ as a formal polity was still a fledgling thing, the recent inheritance of a decades-long effort on the part of successive generations of haole missionaries, industrialists, and lawmakers to undermine the nation's Indigenous monarchy and secure de jure annexation by the United States. Strategically negotiated and openly resisted by Kānaka Maoli of all social ranks through the first half of the century and beyond (Arista 2019; Beamer 2014; Silva 2004), this effort had gained significant ground in the early 1850s, as persistent haole agitation against Indigenous land tenure regimes and the growing threat of forcible colonization from without moved King Kamehameha III to undertake a sweeping land reform initiative known as the Great Māhele. In addition to dividing the total acreage of the Hawaiian Islands into three distinct administrative categories, the Māhele led to the establishment of the kingdom's first laws of private property, the relaxing of restrictions on foreign ownership of land, and the creation of a new title registration system that sought to transform Kāanaka Maoli commoners into rural homesteaders (Kēhaulani Kauanui 2008; Osorio 2002).

The aim, to be clear, was to codify Indigenous control over the islands in a manner that a growing stratum of would-be colonists would recognize and, in principle, be obliged to honor. If, as Bhandar (2018) writes, colonial modernity "ushered in a relationship between ownership and subjectivity, wherein the latter was defined through and on the basis of one's capacity to appropriate" (4), to understand land as something that could be owned, then in transforming Kānaka Maoli land tenure practices such that they were now aligned with "an ideology of the possessive individual" (79), Kamehameha III 
sought to make his kingdom legible as modern - which is to say, possessed of a formal de jure sovereignty that could not be vitiated at will by foreign nationals (Kēhaulani Kauanui 2008). The results, however, would prove disastrous. As haole industrialists leveraged this new framework to consolidate their previously scattered holdings into industrially scaled agricultural concerns, the bureaucratic and financial burdens of title registration conspired to transform the Māhele into a powerful engine of dispossession that left Indigenous commoners denuded of all but about 1 percent of the archipelago's total acreage (Kēhaulani Kauanui 2008). This grim situation bears out Bhandar's understanding of title registration as a foundational element of the racial regime of ownership. Referring specifically to the Māhele and its aftermath, she asserts: "land titling systems have effectively diminished ways of relating to land that do not conform to capitalist property norms and, once imposed, have worked to the radical disadvantage of Indigenous peoples who do not adopt the formalities of ownership as prescribed by settler [or settler-influenced] laws" (Bhandar 2018, 78).

In the decades that followed, the planters wasted little time in making political hay of their newfound economic clout. By the end of the 1870s, haole industrialists had succeeded in securing a Treaty of Reciprocity with the United States, which had an effect on the Hawaiian economy "somewhat analogous to that of an uninhibited pituitary gland in the human body" (Sur $2008,94)$. And less than a decade later, in 1887, a private haole militia would foist a new constitution on King David Kalākaua, stripping him at gunpoint of the vast majority of his executive powers (Osorio 2002). After assuming the throne in 1891 as Queen Lili'uokalani, Kalākaua's sister Lydia would attempt to reverse these insults by promulgating a new constitution. But before she had the chance, haole militiamen, this time backed by some two hundred US Marines, illegally overthrew her and proclaimed a provisional government (Lili'uokalani 1898; Blount 1893). Though vehemently protested by Kānaka Maoli and initially decried by many US legislators, the White House never took concrete action to reverse the coup (Silva 2004). And in 1898, by a joint resolution of Congress, the United States annexed the Hawaiian Islands outright. The territorial government was formalized two years later. Even so, things remained precarious for the planter class. Most glaringly, their fledgling (and, locally, much reviled) republic remained without any reliable telegraphic link to the US mainland. Indeed, as the century drew to a close, Hawaiian telegraph infrastructure remained limited to a few private lines between retail shops in Honolulu, and a small intra-island system established on Maui in the 1870s (Schmitt 1978). This was a situation that many haole businessmen, especially those in the sugar industry, found profoundly frustrating, utterly dependent as they were on consumer markets and refining facilities half an ocean away. What's more, as word spread that the British were preparing to lay the final, transpacific arm of their globe-encircling telegraph network- the so-called All Red Line-haole legislators began to fear that without a working cable between the islands and the mainland, they were entirely vulnerable to 
the designs of a competing imperial power (Winseck and Pike 2007; Hawaiian Gazette 1893, 3). But where most could discern only crisis and threat, one haole engineer by the name of Frederick J. Cross smelled opportunity.

Born in Buffalo, New York, Cross was already a prominent figure in the world of electrical engineering when he arrived in the Hawaiian Islands in the late 1890s. Having incorporated the first major electrical concern at Niagara Falls, Cross quickly carved out a lucrative niche for himself in the booming, postReciprocity agricultural economy by selling haole sugar barons on the advantages of incorporating hydroelectric power generation and other forms of electrical apparatus into their operations (The Evening Bulletin 1898, 6; The Evening Bulletin 1899, 1). Soon, however, Cross, like so many of his contemporaries, would find himself preoccupied with press reports documenting the work of one Guglielmo Marconi-the young Italian inventor whose novel system of "telegraphy without wires" promised to revolutionize the science and industry of telecommunications. Persuaded that this new apparatus might have a role to play in breaking the Hawaiian telegraphic stalemate, Cross in July 1899 wrote Marconi cold, claiming, as an "Electrical Engineer of US National repute," that "the conditions existing here are almost ideal for the perfect operation of your system between the Islands of this group" (Cross 1899). About a month later, he received an encouraging reply from Henry W. Allen of the Wireless Telegraph and Signal Company in London, reassuring him that "if the distances recorded [in the first letter] are correct," there "will be no difficulty in connecting all the islands" (Allen 1899). This was all the convincing Cross needed. By October, he would be aboard a steamship bound for San Francisco in hot pursuit of a personal audience with Marconi in New York City, where the latter was scheduled to demonstrate his dazzling wares for a number of prospective clients, including a deeply skeptical US Navy establishment (Pacific Commercial Advertiser 1899; Austin's Hawaiian Weekly 1899).

The tiresome sojourn would soon pay dividends. Despite being warned in advance by the syndicate that controlled US licensing rights to Marconi's patents that no contract could be made for a Hawaiian system apart from a broader, national agreement, Cross in late November returned to the islands with just such a contract in hand (Pacific Commercial Advertiser 1899; Austin's Hawaiian Weekly 1899). Upon arrival in Honolulu, he set about formalizing a new telecommunications concern-the Inter-Island Telegraph Company-to develop plans for an archipelago-wide point-to-point wireless system, and more importantly, to drum up some much-needed capital for the ambitious new enterprise (Pacific Commercial Advertiser 1899). Overseen by a small team of Marconi engineers dispatched to the islands from London, experiments began almost immediately, and within a year of the company's founding, the first link in the system, between $\mathrm{O}^{\boldsymbol{c}} \mathrm{ahu}$ and Moloka'i, was operational. It was not long before "the rest of the Islands-Maui, Lanai and Hawaii [were] linked by the mysterious electrical waves" (Pacific Commercial Advertiser 1900, 1). 
Perhaps unsurprisingly, given the pointed political and economic stakes of marginality, these developments were greeted with great enthusiasm in the establishment press, with the papers of Henry M. Whitney leading the charge. Always a strident supporter of US annexation, Whitney, in his younger years, had nonetheless distinguished himself by using his papers (particularly the influential Pacific Commercial Advertiser) to denounce the "bloated monopolists" of the haole planter class. This iconoclastic posture, however, would be short-lived: in 1870, a group of Maui sugar producers initiated an advertising boycott of the $P C A$, forcing Whitney to sell the paper under financial duress to a pair of printers who, "financed by the planters...immediately reversed the editorial line" (Geracimos Chapin 1996, 56). As a result, by the turn of the century, the Advertiser, along with Whitney's other papers, including the Hawaiian-language Ka Nupepa Kuokoa, had been returned to the "orthodox fold," where they went on beating the twin drums of industrial expansion and US political hegemony (Geracimos Chapin 1996, 56).

This orientation was clear in their laudatory coverage of the new wireless system. The $P C A$, for instance, reported glowingly of the "smile of triumph" that appeared on Cross's face when the O'ahu-Moloka'i link was brought online, and gave him space to proclaim, somewhat disingenuously, that "the wireless telegraph system in the Hawaiian Islands is an unqualified success" (Pacific Commercial Advertiser 1900, 1; quotations that follow are also from this article). In keeping with this celebratory tone, the rest of the report tells a triumphant story of modern industrial grit conquering retrograde mysticism and obstinate material constraint. "After months of struggling with the mysterious forces which Signor Marconi discovered and meeting with skepticism at every hand of late," the author continues, "[Cross] has the satisfaction of knowing that his efforts have been crowned with success." In the next paragraph, this trope recurs, as if for emphasis: "Not only has the wireless communication been established between the Islands of Oahu and Molokai, but the rest of the Islands-Maui, Lanai, and Hawaii are linked by the mysterious electrical waves." But if this was a story of industrial achievement, it was also one of sublimity and transcendence-a story about the kind of world that takes shape, or becomes possible, once the ether has been drawn into the fold of industrial practice. As the author observes, not only did these "mysterious waves" provide for robust inter-island connectivity, they also promised to "make it possible for all to put themselves in communication with their friends hundreds of miles away in a very short time." By dint of wireless connectivity, "hundreds of miles" are squeezed into "a very short time": a vertiginous restaging of spatial as temporal distance that the author repeats a few paragraphs on, writing "Thus the Molokai channel, more than forty miles wide, was bridged in five seconds." At a time when anxieties over the potentially disastrous costs of marginality were running high, this remarkable displacement would surely have come as welcome news to the $P C A$ 's haole readers. 


\section{HE UWEA OLELO ANO HOU LOA.}

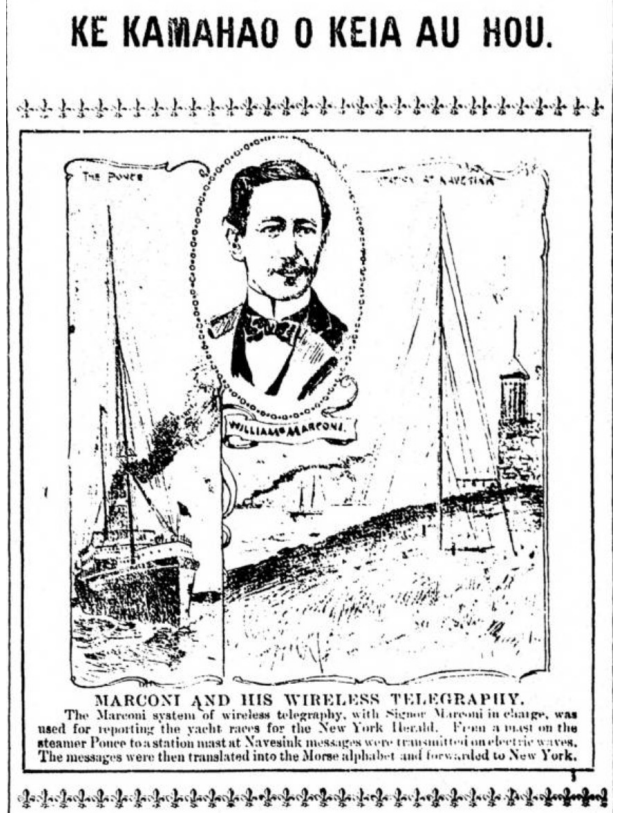

Figure 3: Clipping from November 10, 1899, edition of Ka Nupepa Kuokoa. The image and headline accompanied a Hawaiian-language article focused on wireless telegraphy and F. J. Cross's Marconi franchise.

Source: Papakilo Database.

Similar themes run through accounts of Cross's franchise published in Whitney's Ka Nupepa Kuokoa, which, though staffed with Kanaka Maoli writers and editors, generally toed the same pro-US, pro-business editorial line that colored the PCA's reporting. Proclaiming the wireless "ke kamahao o kei au hou," or "the wonder of this new age," a November 1899 report on Cross's new telecommunications concern evinces a clear enchantment with the scalar possibilities of this "uwea olelo ano hou loa," this most new kind of telephone (Nupepa Kuokoa 1899, 2).

Accompanied by a cameo-style portrait of Marconi (erroneously identified, or perhaps Anglicized, as William) superimposed on an artist's rendering of a recent demonstration of his wireless system at the America's Cup regatta off the coast of Sandy Hook, New Jersey, the article begins, "Aole paha e liuliu loa na la mai keia wa aku a hoea mai i o kakou nei he Uwea Olelo ano nou loa o kona launa kamailio ana, mawaena o kahi kanaka ame kahi kanaka, e ku ana ma kahi mamao mawaena o laua." Roughly translated: "it may not be too long [much longer, many more days] from now that we will receive a most new kind/type of telephone [Uwea Olelo, literally, language wire or speaking wire] that will establish communication between one person and another person standing/located at a distance from one another." Here, not only does the text indulge an enticing fantasy of spatial contraction that the $P C A$ will replicate almost exactly a year later, the newspaper page itself functions as a scene of 
virtual transit and geographic compression, visually collapsing the distance between Sandy Hook and O'ahu in a manner that prefigures the strange new proximities associated with the wireless.

\section{Race, Labor, Land: The End of Inter-Island}

It would not be long, however, before Cross would find himself mired in a range of financial and legal disputes that, in addition to casting a chill on this celebratory rhetoric, would underscore the degree to which his collaboration with British Marconi depended upon the machinations of colonial proprietorship and its adjoining techniques of racialization. As noted above, Cross had arrived in the islands sometime in 1898 and had wasted little time in establishing himself as a leading authority on hydroelectric power generation. Indeed, within a year of his arrival, Cross was already overseeing the installation of hydroelectric apparatus for such prominent clients as Hermann A. Widemann and Julius Richardson, whose powerful Waianae Sugar Company comprised substantial holdings along O'ahu's eastern and northern shores (The Evening Bulletin 1899, 1). Given these connections, it comes as little surprise that when it came to staffing up his new wireless concern, Cross would tap some of the most prominent members of the haole industrial elite. Included on Inter-Island's first board of directors, for instance, were figures like W. W. Hall and E. O. White, a father-and-son merchant duo who also happened to be zealous annexationists (Farrington 1902). Not only had Hall participated personally in the 1887 constitutional coup against Kalākaua, in 1893, he and White had also played an instrumental role in Lili'uokalani's ouster, stockpiling weapons in the storeroom of their Honolulu retail shop and allowing haole militiamen to use the facility as a staging area for the overthrow (The Daily Bulletin 1887, 3; Blount 1893, 320).

His partners' clout, however, did little to shield Cross from the ire of the Wireless Telegraph and Signal Company, which already by 1900 had begun to take stiff exception to his hiring and staffing practices. In a letter to Cross dated December 29, 1900, for instance, chief Marconi engineer Andrew Gray lamented, "After being nearly two months in these Islands I am much disappointed to find that instead of improving the relation between the Marconi Company and yours it has become more strained... Your codirectors want demonstrations and yet they fail to provide the operators necessary to give demonstrations" (Gray 1900b). These concerns would only escalate in the new year. In late January 1901, Gray wrote to Cross once again, this time to inform him that he had terminated no fewer than five operators, three of them Japanese (Gray 1901a). And in March, Gray would write yet again to complain that while his engineers "have had the system installed and in working order since Feb 1st last," the ongoing "failure to run it has been caused partly by the blowing over of the poles which you constructed, and partly by the class of operators you have sent out" (Gray 1901b). While such complaints may well be read as a rather predictable attempt to shift blame for larger structural and administrative problems onto the shoulders of operators, Gray's criticisms are 
also suggestive of the degree to which the colonial plantation economy had reorganized the Hawaiian labor market over the previous five decades, carving new and deeply racialized distinctions between particular classes of worker.

As haole industrialists began to scale up their sugarcane operations in the wake of the Māhele, they quickly found themselves in need of a much-expanded workforce capable of felling this most labor-intensive of crops. To this end, the planters began to lobby the Hawaiian government to establish a new law that would provide for the importation of indentured workers from across the Asia-Pacific. In 1850, the same year the kingdom's new title registration and ownership laws went into effect, these efforts came to fruition with the passage of the Masters and Servants Act. In addition to authorizing the importation of indentured workers first from mainland China and, in later years, Japan, Portugal, and the Philippines, this new law simultaneously established a racialized "hierarchy of value," whereby migrant and Indigenous workers were differently governed on the basis of prevailing conceptions of the latter as essentially indolent and lacking in work ethic, and of the former as industrious but often underhanded or venal, and thus in need of explicitly penal forms of discipline. To wit, under the terms of the act, foreign laborers were contracted to specific plantations for work terms of up to a decade in length, during which time they were immediately subject to the demands and needs of their employers. Any failure to satisfy the terms of these contracts, moreover, was punishable by prison sentence (Sur 2008; Beechert 1985). Agricultural contracts for Kānaka Maoli, meanwhile, were limited to five years. While this "stated difference in the terms of the contract" certainly "symbolized the prejudice against immigrant labor" that obtained among the haole sugar barons, it also served to make Indigenous workers decidedly less attractive to prospective employers (Sur 2008, 91). Shorter contract periods, after all, meant an attenuated window over which to amortize the costs of worker recruitment and maintenance. As a result, while indentured Chinese and Japanese workers found themselves squarely in the crosshairs of intensive labor exploitation and penal discipline, their Indigenous counterparts were pushed even further toward the economic margins. Dispossessed of their lands and increasingly shut out of the emerging wage economy, thousands of Kāanaka Maoli commoners left the islands through the 1860s and '70s, pursuing work mining gold in California, cutting sandalwood in China, and whaling and gathering guano across the Pacific (Rosenthal 2018). The Masters and Servants Act, in this sense, played a key role in the consolidation of a racial regime of ownership in the Hawaiian Islands, "twinning the production of racial subjects with an economy of private property" such that efforts to extinguish "Indigenous and alternate modalities of relating to and using land and its resources" coincided temporally and structurally with a new system of labor discipline that accorded value to distinct classes of workers on the basis of racial type (Bhandar 2018, 7). 
Though formulated specifically in response to the demands of the planter class, this same regime would soon prove vital to the emergence of the Hawaiian telecommunications industry. As the decades wore on and increasing numbers of indentured workers served out their plantation contracts, Chinese and Japanese immigrants began making inroads in other sectors of the colonial economy, establishing themselves as merchants, restaurant and café owners, theater operators, and dockworkers. Wages, though, remained highly stratified along racial lines, with most immigrant workers unable to command rates of compensation on par with their haole counterparts. Cross, it seems, was only too willing to exploit this racialized hierarchy of value, recruiting from the swelling ranks of the "free" immigrant working class a cohort of operators whom Marconi's men derided as "absolutely incapable of managing the instruments" and "unable to speak English properly" (Pletts, n.d.). At a shareholder meeting in 1902, Marconi himself would make the racism latent in these attacks explicit, blaming the failure of the Hawaiian enterprise not only on Cross's (mis)management but also on "the inferior class of the operators-frequently ignorant half-breeds and negroes-whom the Hawaii company was ill-advised enough to employ for reasons of very false economy" (Raboy 2016, 135). What's more, while the telecommunications industry lacked the sort of penal disciplinary mechanisms the Masters and Servants Act had put at the disposal of the sugar barons, Cross's operators appear to have faced working conditions strikingly akin to those that had prevailed on the plantation. Pay was low; so low, in fact, that operators routinely walked off the job, or were summarily fired by managers dissatisfied with their performance (Raboy 2016). In an undated letter to Major Stephen Flood-Page, managing director of the Wireless Telegraph and Signal Company, J. S. Vincent Pletts, one of Gray's subordinates, even goes so far as to suggest that if Cross were to recruit "a better [read: white] class of operators...the salaries would have to be nearly doubled" (my emphasis). Another document, undated and unsigned, estimates that with "at least one white operator" installed at each node, the cost of running the system would increase from about six to pounds per station per day to about ten pounds per station per day ("Hawaii," n.d.).

Accommodations were also decidedly subpar. In the same letter to FloodPage, Pletts laments that in the event of a transition from free immigrant to white labor, "all the station houses...would have to be rebuilt as no white man would live in the huts which have been constructed." On this score, Pletts was prescient. In the months prior to the opening of the stations at Kahuku and Koko Head, the establishment would boast of the plush accommodations available at the new facilities. At Koko Head, for instance, operators were to be "installed in a commodious two-story building which will contain elaborate preparations for the comfort and recreation of the employes [sic]. It will be built on the plan of a hotel, with rooms for each employee, billiard rooms, etc., while tennis courts, a swimming tank, a baseball diamond and several other features will be provided" (Case 1913, 16). Other amenities included a beachside bathhouse, a full sewer and plumbing system, electric lighting, 
and standalone residences for more senior operators and administrators (Case 1913, 16). These developments, however, would not come to pass on Cross's watch. In 1901, with disputes over staffing unresolved, Cross "reneged on paying the second installment for the first year of the contract and denied his personal liability" for the expense (Raboy 2016, 134). In response, the Wireless Telegraph and Signal Company filed suit against Cross in the First Judicial Circuit Court of the territory of Hawaii, seeking \$5,500 to cover the unpaid contract, plus an additional five hundred British pounds to cover a year's worth of back equipment rental fees (Marconi Wireless Telegraph and Signal Company Ltd., Plaintiff, vs. Frederick J. Cross, Defendant 1901).

But even as this acrimonious falling-out put a decisive end to Cross's foray into the world of ICT development, it created an opportunity for Marconi's recently incorporated US subsidiary, the Marconi Wireless Telegraph Company of America (hereafter American Marconi), to foist its own designs on the islands. To wit, by 1908, American Marconi had established a new experimental receiving station at Kahuku, eyeing the prize of transpacific connectivity. Not long after, in 1912, one of the company's main competitors, the California-based Federal Telegraph Company, succeeded in establishing the archipelago's first commercial wireless circuit with San Francisco, using a newly constructed transmitter at He'eia (Schmitt 1978, 112; Honolulu StarBulletin 1912). In response, American Marconi moved quickly to consolidate its position in the islands, making plans for a much-expanded station at Kahuku and a new companion station at Koko Head. To secure land for the former, American Marconi engineer F. M. Samis turned to the estate of James Campbell (Case 1913, 16), a haole industrialist of Irish extraction who had arrived in Hawai' $i$ in 1850, just as title registration, property law, and the importation of indentured labor were constellating into a thoroughly racial regime of ownership. Campbell, like many of his counterparts, was quick to exploit these developments, acquiring substantial tracts of land on $\mathrm{O}^{\prime} \mathrm{ahu}$, Maui, and Hawai'i Island, which he then leased at a handsome profit to the many planters looking to make the most of the sugar economy (James Campbell Company 2003).

In 1876, Campbell made a shrewd addition to his already substantial portfolio, purchasing some fifteen thousand acres of dry, windswept plain at Kahuku from none other than Hermann A. Widemann (one of Cross's first hydroelectric clients), which he then equipped with a mechanical irrigation system to render the land suitable for sugar cultivation. In 1889 Campbell leased the entirety of the Kahuku property, along with his holdings at 'Ewa Beach, to the haole industrialist B. F. Dillingham, whose business consisted primarily in large-scale dredging projects and railway construction (James Campbell Company 2003; Siddal 1997, I:89). In short order, Dillingham subleased one portion of the Kahuku property to James B. Castle, who in 1890 used it to establish the Kahuku Plantation, and another to W. R. Castle, who in turn established the Ewa Plantation Company (James Campbell Company 


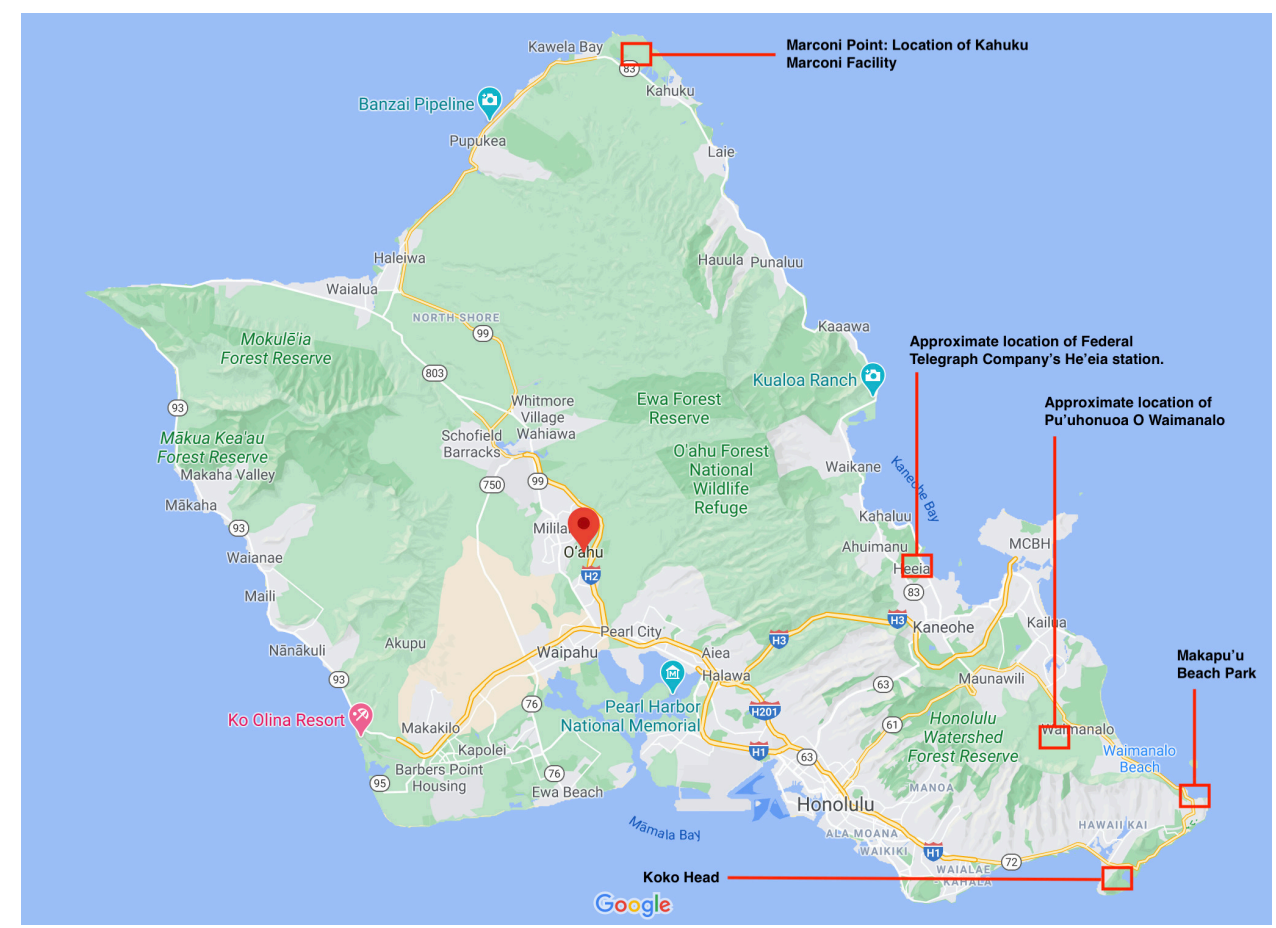

Figure 4: Map of $\mathrm{O}^{\mathfrak{c}} \mathrm{ahu}$, showing location of major Marconi installations and other relevant sites.

Map: Google Maps. Annotations by the author.

2003). Thus by the time Samis, in 1912, negotiated a lease for a plot of land that would play host to the expanded Kahuku wireless station, the site was completely surrounded by industrially scaled cane harvesting operations-quite literally ensconced within a territorial and economic order elaborated around formal rights of private possession, intensive agricultural extraction, and racialized labor exploitation. Marconi Farms, indeed.

Though the collapse of the Inter-Island Company had thrown some cold water on the sort of ethereal speculation in which haole reporters had so liberally indulged a decade prior, by 1913, with the openings at Kahuku and Koko Head imminent, this rhetoric had returned to the pages of the establishment press in full force. For its part, the Star-Bulletin (founded by Henry Whitney in 1882, and now owned by Joseph Ballard Atherton, who, like Cross's associates W. W. Hall and E. O. White, had played a key role in Lili'uokalani's ouster) promised that the new stations would "Flash Aloha Round [the] World" (1914a), casting that most recognizable signifier of "Hawaiianness" as the harbinger of an incipient globality, and prefiguring later efforts on the part of so many hoteliers and tour promoters to transform aloha into a kind of global brand for the islands (Ohnuma 2008; Teves 2015; Imada 2008). A few months later, the paper would again forge a novel set of scalar articulations as a way of underscoring the significance of the facilities, declaring, "Wireless Telephone System Around the Globe is Dream of Marconi About Realized-Hawaii to be Link Between the Mainland, the Orient, and Australasia." If this headline left any doubt as to the import of these linkages, which promised to turn familiar configurations of centrality and peripherality on their heads, the 
accompanying article dispelled it. Quoting Marconi director Goddfrey Isaacs, the author writes, "Power will overcome distance...Wireless communication stands at the threshold of unrevealed immensities" (Honolulu Star-Bulletin 1914a). Small wonder that when the twin plants finally opened in the fall of 1914 , the Star-Bulletin would not hesitate in proclaiming

[a] new era in transpacific and world-communication for the people of Hawaii. With the opening of two great wireless stations on Oahu by the Marconi Wireless Telegraph Company of America, Uncle Sam's midpacific territory is brought closer and is bound closer than ever to her sister commonwealths of the mainland. Day and night, through the medium of the wireless, Hawaii is in continuous touch with the mainland stations of the Marconi company, and the completion and opening of the local plants mark also the forging of a new link in a chain of Marconi stations soon to extend around the world. (Honolulu Star-Bulletin 1914c, 8)

Of course, accounts such as these may be readily dismissed as mere advertorial-celebratory paeans to the achievements of modern industry that do little to question or even to qualify the grandiose claims of corporate promoters. Read against the history recounted above, however, they appear as something more substantial than this, offering evidence of just how intimately involved the technics and indeed the fantasy of wireless connectivity had become in efforts to not only imagine but also materially enact a specifically colonial arrangement of Hawai' $i$, the Pacific, the United States, and the globe-an arrangement in which the dream of transcending geopolitical and economic marginality came to be constitutively bound to the machinations of colonial proprietorship. Indeed, what I hope to have made clear is that if the wireless managed to enliven a new model of scale and connectivity among the archipelago's haole elite - if it made it possible to see these islands as firmly within Uncle Sam's imperializing grasp, yet at the same time very much of a Pacific that increasingly appeared as the proper horizon of the global-it did so precisely because it took shape within and through those processes of Indigenous dispossession, territorial enclosure, and racialized labor exploitation constitutive of the racial regime of ownership.

\section{Other Ether-realities}

What began with a bang would, in its course, end with a whimper. In 1917, a mere three years after the pomp and clamor at Kahuku, the United States officially entered the First World War against Germany. On April 6 of that year, President Woodrow Wilson, seeking recourse to the 1912 Act to Regulate Radio Communication decreed by executive order that all US wireless receiving and transmitting stations, including American Marconi's installations on O'ahu, were to be "taken over by the Government of the United States and used and controlled by it, to the exclusion of any other 
control or use" (Wilson 1917). And while war's end would see corporate control of the stations restored, the US Navy establishment, always skeptical of the Marconi Company and the iconoclastic inventor whose name it bore, remained deeply concerned at the prospect of an international radio communication system dominated by British rather than American interests. To rectify this perceived threat, naval administrators compelled the General Electric Corporation to buy out American Marconi and establish in its place a US-owned radio subsidiary to be known as the Radio Corporation of America, or RCA (Streeter 1996, 82-83). And as went the company so, eventually, went the stations at Kahuku and Koko Head. By the mid-1920s, the rapid pace of technical and regulatory change in the broadcasting industry had rendered the facilities more or less obsolete. No longer profitable, the campuses were left to crumble, while the surrounding lands were progressively repurposed to suit changing civilian and military needs.

But while the facilities themselves were ultimately fleeting, the models of scale and connectivity they had helped to cultivate would prove far more durable. Indeed, as the twentieth century wore on, wireless ICT development and its attendant imaginaries of untrammeled communication would remain bound up in the maneuvers of colonial governance, helping to animate lucrative new configurations of proximity even as the unwilled up-againstness of the colonial situation remained a site of intense friction in the Hawaiian Islands and across the Pacific. In the 1930s, for instance, commercial broadcasting became pivotal to efforts to make Hawai'i legible to mainland listening publics, helping to position the archipelago as an altogether US-American yet still enticingly exotic space of leisure and consumption - a place where the "gap of racial difference" could be safely consumed as touristic commodity (Smulyan 2007; Ohnuma 2008, 374). Similarly, during and after the Second World War, the density of wireless signal traffic in and around the islands would escalate dramatically, as the archipelago found itself on the front lines of US (counter)propaganda, signal intelligence, and surveillance operations first against Japan, and in later years, the USSR and its allies in Southeast Asia (Smulyan 2007; Sheppard 2001). In this period, cutting-edge wireless infrastructures, including longrange radar installations, satellite ground stations, and even radio-linked computer networks like the ALOHAnet proliferated across the islands, transforming them into a key node within an emerging transpacific communications environment that Oldenziel (2011) rightly describes as a "networked empire"-a sprawling technopolitical and administrative formation that deranged Indigenous lands, waters, and lives from $\mathrm{O}^{\prime}$ ahu to Kwajalein, and from Bikini to Diego Garcia.

To be sure, these developments help to highlight the remarkable obstinacy of colonial ways of conceptualizing and governing the world, pointing up the tenacity with which they persist in subordinating diverse peoples, territories, and ways of being to their own ends. By the same token, however, they also reveal the essentially contingent character of the racial regime of ownership, 
underscoring how its constituent elements stretch and shift in response to changing technical, infrastructural, cultural, and geopolitical conditions. As Bhandar (2018) writes, drawing on the work of Stuart Hall in particular, "there are no guarantees that a given articulation of race and property ownership will appear in the same configuration across time or jurisdictions" (13). While this is partly "because of the sheer heterogeneity contained within articulations of race and property ownership," it is also because as spatialized techniques for the governance of land, people, and markets, colonial regimes of property and race are themselves constantly being reorganized by diverse forms of technicized communication, and the imaginaries of proximity, distance, and scale to which they give rise (Bhandar 2018, 13). If this is the case, if racial regimes of ownership are suspended in a state of "continual renewal," then however obstinate, they are also essentially and always incomplete (Bhandar 2018, 13). The juridical, cultural, and technical means by which they reproduce themselves are thus always potential sites of disruption - points at which other imaginaries and other models might obtain.

Might, then, something other than the colonial order of things be born of the history I have recounted here? If etherealization, as Thibault argues, involves a reordering of the physical world, might wireless ICT development open toward what Walter Mignolo (2010, 2013) has called the decolonial option, carving out some space for a model of connectivity that, somewhat paradoxically, delinks from the racial regime of ownership that has taken shape in the Hawaiian Islands over the last two centuries, and roots itself instead in some other ordering of land, life, and infrastructure? Recent developments suggest not only that such an opening is possible, but that it may already be underway. Over the course of fifteen months in 1993 and 1994, a group of some three hundred low-income and unhoused people, mostly Kānaka Maoli, staged an occupation of Kaupo Beach Park at Makapu'u, on O'ahu's eastern shore, not far from Koko Head. The timing of the action was both auspicious and strategic, coinciding with the hundredth anniversary of Queen Lili'uokalani's ouster at the hands of the haole planter class (Hurley 2014). Led by well-known activist Dennis "Bumpy" Kanahele, the occupation took shape under the aegis of the Kanaka Maoli sovereignty organization, Nation of Hawai' $i$, which advocates both for political independence from the United States and for a restoration of the Hawaiian monarchy (Kanahele 2017, 2018). ${ }^{3}$

\footnotetext{
3 It bears noting that, in this respect, the Nation of Hawai' $i$ is loosely aligned with a particular group of sovereignty activists that J. Kēhaulani Kauanui calls "Kingdom Nationalists." This cohort tends to quite vigorously disavow the discourse of Indigeneity and opposes the notion that the situation of Native Hawaiians is in any substantial way equivalent to that of mainland Native Americans. A detailed account of this position can be found on the blog of the organization Hawaiian Kingdom: https://hawaiiankingdom.org/blog/the-hawaiian-sovereignty-movementoperating-on-a-false-premise/. While Kingdom Nationalist discourse is indeed a significant strain within the larger Hawaiian Sovereignty Movement, the two are not precisely equivalent to one another. Many Kānaka Maoli, in fact, take exception both with the project of monarchial restoration, as well as with the problematic ways in which some Kingdom Nationalists characterize Native American tribal governance arrangements. These dynamics have been addressed more fully by Këhaulani Kauanui in Paradoxes of Hawaiian Sovereignty and Jodi Byrd in The Transit of Empire. I do not mean to deliberate or decide upon these perspectives here, and as a white settler scholar, it is not my place to do so. I aim only to mark terms like "sovereignty," "kingdom," and "nation" as highly contested ones in the contemporary Hawaiian context.
} 
As the occupation dragged on, $\mathrm{O}^{\prime}$ ahu mayor Frank Farsi found himself under increasing pressure from tourists and area residents alike to put an end to the demonstration. In the hopes of doing so, Farsi would eventually resort to cutting off water to the park's restroom facilities and encasing the plumbing controls in concrete (Nakaso 2018). In response, Kanahele agreed to conclude the demonstration on the condition that the state of Hawai' $i$ grant him a fifty-year lease on a plot of public land near the town of Waimannalo. The state conceded, and on that land Kanahele would proclaim an entirely new community: $\mathrm{Pu}$ 'uhonua $\mathrm{O}$ Waimānalo, invoking the precontact practice of declaring certain politically or culturally significant sites $\mathrm{Pu}^{\text {' uhonua, or places }}$ of refuge (Kame'eleihiwa 1992). More than a place for the unhoused, however,

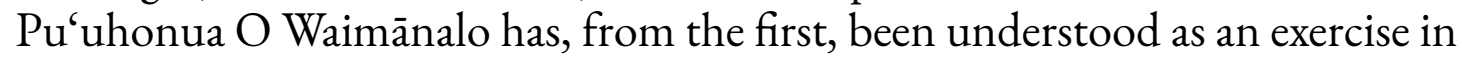
Kānaka Maoli sovereignty. For its residents, the refuge is "a land base for the developing sovereign Hawaiian nation, where Kānaka Maoli and our extended 'ohana are living close to the 'aina in a self-determined taroroots community dedicated to cultural, social, political, and economic advancement of the people” (Pu'uhonua O Waimānalo, n.d.).

A quarter century on from its founding, the community in 2018 undertook an important step in its ongoing development, forging a partnership with the Internet Society to build a community-wide wireless mesh network aimed at providing all residents with reliable, low-cost access to the internet (RoseSmith 2020). Given the peculiar infrastructural constraints facing the refuge, the need for such a network is acute. On the one hand, like many Indigenous communities elsewhere in the world, Kānaka Maoli in Hawai' $i$ are generally underserved by local incumbent carriers, who tend to balk at the cost of extending broadband connectivity to areas where spending power and access to consumer credit tends to be below regional and national averages (see Duarte et al. 2020; McCallum and Papandrea 2009). On the other hand, because the refuge is less than twenty miles from the major urban center of Honolulu, it also tends to "get left out of the picture" when it comes to accessing grants aimed specifically at building out broadband capacity in rural and low-income locales (Maka'awa'awa 2019a). As a result, until quite recently, residents of the refuge have relied heavily on expensive mobile data networks and unreliable commercial Wi-Fi hotspots to access the internet. A distributed wireless mesh, administered and maintained from within, provides a much-needed route around these constraints, promising "affordable access to the Internet and the limitless opportunities it can provide" (Maka'awa'awa 2019b). In this respect, the initiative is part and parcel of a growing global movement to build what Greta Byrum (2019) calls a "People's Internet": a flexible, sustainable, and truly distributed network of networks, governed not by the economic interests of incumbent carriers or compliant state regulators, but rather by the values of specific communities of users who, together, determine what forms of connectivity and what strategies of infrastructural development best suit their particular needs and aspirations (see also Greig 2018; Middleton and Crow 2008; Guo 2017). 
At Waimānalo, these needs certainly include economy, reliability, and speed. Also at stake, however, is the question of Indigenous sovereignty. "The community network," writes Brian Maka'awa'awa, deputy head of the Nation of Hawai' $i$ and nephew to Kanahele, "is very important to helping us to achieve our goal of total independence... Having our community become its own Internet provider will...help us build a self-sustaining solution to create more independence for our Nation” (Maka'awa'awa 2019b). At Waimānalo, wirelessness thus becomes a method of Kānaka Maoli nation building: "In order for our sovereign nation to evolve independently, it is critical that we have control over our connectivity. We consider this national infrastructure" (Maka'awa'awa 2019b). These claims suggest that if the Pu'uhonua O Waimānalo mesh initiative is broadly aligned with an emerging movement to build a "People's Internet," it is also the inheritance of a specifically Indigenous history of media activism in which community governance of ICT infrastructures is understood as a means not simply of overcoming technical deficiency or expanding access, but of shifting the promise of scalable connectivity onto alternative ethical and political foundations, and of subordinating it in turn to decolonial world-making projects. We might consider, for instance, the case of Imparja TV, a satellite television network established in the late 1980s by a consortium of Aboriginal Australian "media groups, communities, and land councils” (Parks 2005, 47). As Lisa Parks (2005) writes, Imparja is unique "not only in terms of the Indigenous content it distributes, but also in its use of the satellite as a means of territorial reclamation and cultural survival in postcolonial Australia" (48). Where the elite development initiatives of the late Cold War years generally "used satellites in an effort to 'modernize' rural populations in developing countries such as India and Brazil," Imparja, Parks continues, instead "appropriate[ed]...an Australian national satellite to support postcolonial Aboriginal struggles for territory, cultural autonomy, and social equality" (48).

In like fashion, Marisa Duarte (2017) has shown how Indigenous communities throughout the American Southwest have in recent years undertaken the complex work of establishing their own ISPs not simply as a means of filling the many unmarked dead zones that pockmark corporate service maps, but also as a means of "accomplishing distinctly Native governance goals" (6). "Information," writes Duarte, "is not 'free' in Indian Country, and it is certainly not free-flowing; rather, it is shaped by...histories of colonization, linguistic choices, ceremonial cycles, protocols of respect, and values around sovereignty, revitalization, and tribal governance needs" (53, my emphasis). Such is certainly the case at Waimānalo, where the work of network development involves not just the pragmatics of communication engineering but also-and more centrally - the articulation of a new model of connectivity, a new conception of what it means, and why it matters, to be in touch both locally and at scale. Nourished on and nourishing of the decolonial ethos on which the refuge was founded, this is a model that refuses to predicate the possibility of connection on the machinations of colonial proprietorship, 
that delinks from the racial regime of ownership in and through which the Marconi enterprise took shape-a model that grows not from the plantation but from the "taroroots" that connect Kānaka Maoli genealogically, ethically, and politically to their territories. It is a model, then, not just of a system or of a network topology, but of a different sort of physical and political world: a decolonial ether-reality.

\section{Acknowledgments}

This research was supported in part by a doctoral fellowship from the Social Sciences and Humanities Research Council of Canada. I would like to thank Dr. Cristina Venegas of UC Santa Barbara for her thoughts on a very early version of this essay. I am grateful, as well, to the reviewers who provided such thoughtful and encouraging feedback. I would also like to thank Dr. Christina Vagt, Dr. Wolf Kittler, and Dr. Sebastian Vehlken for inviting me to participate in the "Modeling the Pacific" symposium at UC Santa Barbara, and for providing me the opportunity to contribute to this exciting new stream of Media+Environment. 


\section{REFERENCES}

Allen, Henry W. Letter to F.J. Cross. 1899, August 2, 1899. Correspondence and Papers Concerning the Hawaiian Islands Contract, 1899-1901. Marconi Archive, Bodleian Libraries, University of Oxford (Shelfmark: MS Marconi 179).

Arista, Noelani. 2019. The Kingdom and the Republic: Sovereign Hawaii and the Early United States. Philadelphia: University of Pennsylvania Press. https://doi.org/10.9783/9780812295597.

Austin's Hawaiian Weekly. 1899. “Mr. F.J. Cross,” October 7, 1899. Chronicling America.

Badino, Massimilano, and Jaume Navarro. 2018. "Ether-The Multiple Lives of a Resilient Concept." In Ether and Modernity: The Recalcitrance of an Epistemic Object in the Early Twentieth Century, edited by Jaume Navarro, 1-13. Oxford: Oxford University Press.

Beamer, Kamanamaikalani. 2014. No Mākou Ka Mana/Liberating the Nation. Honolulu: Kamehameha Publishing.

Beechert, Edward D. 1985. Working in Hawaii: A Labor History. Honolulu: University of Hawai' $\mathrm{i}$ Press.

Bhandar, Brenna. 2018. Colonial Lives of Property: Law, Land and Racial Regimes of Ownership. Durham, NC: Duke University Press. https://doi.org/10.1215/9780822371571.

Blount, James H. 1893. Papers Relating to the Mission of James H. Blount, United States Commissioner to the Hawaiian Islands. Washington, D.C.: US Department of State. Hathi Trust.

Byrd, Jodi A. 2011. The Transit of Empire: Indigenous Critiques of Colonialism. Minneapolis: University of Minnesota Press. https://doi.org/10.5749/minnesota/9780816676408.001.0001.

Byrum, Greta. 2019. "Building the People's Internet." Urban Omnibus, 2019. https://urbanomnibus.net/2019/10/building-the-peoples-internet/.

Carey, James. 1988. Communication as Culture: Essays on Media and Society. New York: Taylor \& Francis.

Case, H.D. 1913. "Greatest Wireless Station in the World Now Being Erected at Koko Head, Oahu, As Part of Globe-Encircling Marconi System Which Will Revolutionize Communication.” Honolulu Star Bulletin, April 19, 1913. Chronicling America.

Cross, F.J. Letter to Guglielmo Marconi. 1899, July 5, 1899. Correspondence and Papers Concerning the Hawaiian Islands Contract, 1899-1901. Marconi Archive, Bodleian Libraries, University of Oxford (Shelfmark: MS Marconi 179).

Duarte, Marisa Elena. 2017. Network Sovereignty: Building the Internet Across Indian Country. Seattle: University of Washington Press.

Duarte, Marisa Elena, Morgan Vigil-Hayes, Ellen Zegura, Elizabeth Belding, Ivone Masara, and Jennifer Case Navares. 2020. “'How a Squash Plant Grows:' Social Textures of Sparse Internet Connectivity in Rural and Tribal Communities." Association for Computing Machinery 1 (1): $1-29$.

Farrington, W.R. 1902. "Wireless Telegraphy Established in Hawaii." In Thrum's Hawaiian Almanac and Annual, edited by Thomas G. Thrum, 189-91. University of Hawai'i Mānoa eVols.

Geracimos Chapin, Helen. 1996. Shaping History: The Role of Newspapers in Hawai $i$. Honolulu: University of Hawai'i Press. https://doi.org/10.1515/9780824864279.

Gray, Andrew. Letter to F.J. Cross. 1900a, November 27, 1900. Correspondence and Papers Concerning the Hawaiian Islands Contract, 1899-1901. Marconi Archive, Bodleian Libraries, University of Oxford (Shelfmark: MS Marconi 179). 
- - L Letter to F.J. Cross. 1900b, December 29, 1900. Correspondence and Papers Concerning the Hawaiian Islands Contract, 1899-1901. Marconi Archive, Bodleian Libraries, University of Oxford (Shelfmark: MS Marconi 179).

- - - Letter to F.J. Cross. 1901a, January 25, 1901. Correspondence and Papers Concerning the

Hawaiian Islands Contract, 1899-1901. Marconi Archive, Bodleian Libraries, University of Oxford (Shelfmark: MS Marconi 179).

- - - Letter to F.J. Cross. 1901b, March 28, 1901. Correspondence and Papers Concerning the Hawaiian Islands Contract, 1899-1901. Marconi Archive, Bodleian Libraries, University of Oxford (Shelfmark: MS Marconi 179).

Greaves, Matthew. 2018. "Empire and Dispossession: Coal Communication and the Labor Process at the Origins of Capitalism in British Columbia, 1849-1903.” PhD diss., Simon Fraser University. Summit. Identifier: etd20001.

Greig, Alexander. 2018. "Wireless Mesh Networks as Community Hubs: Analysis of Small-Scale Wireless Mesh Networks and Community-Centered Technology Training.” Journal of Information Policy 8: 232-66. https://doi.org/10.5325/jinfopoli.8.2018.0232.

Guo, Eileen. 2017. "Without Net Neutrality, Is It Time to Build Your Own Internet?” Inverse, December 22, 2017. https://www.inverse.com/article/39507-mesh-networks-net-neutrality-fcc.

"Hawaii." n.d. Correspondence and Papers Concerning the Hawaiian Islands Contract, 1899-1901. Marconi Archive, Bodleian Libraries, University of Oxford (Shelfmark: MS Marconi 179).

Hawaiian Gazette. 1893. "The Hawaiian Cable," February 14, 1893. Chronicling America.

—-_. 1914. "Marconi Wireless Is Formally Opened by Governor Pinkham,” September 25, 1914. Chronicling America.

Honolulu Star-Bulletin. 1912. "May Now Flash Word to Coast by Day Wireless," November 18, 1912. Chronicling America.

- - . 1913. "Greatest Wireless Station in The World Now Being Erected At Koko Head, Oahu, As Part of Globe-Circling Marconi System Which Will Revolutionize Communication,” April 19, 1913. Chronicling America.

-_-. 1914a. "Wireless to Flash Aloha Round World," April 15, 1914. Chronicling America.

- - . 1914b. “Great Marconi Plant Is Opened, Celebration Marks Wireless Feat,” September 24, 1914. Chronicling America.

- - . 1914c. "Hawaii an Important Link in the Globe-Encircling Radio Chain," September 24, 1914. Chronicling America.

Hurley, Timothy. 2014. "Activist 'Bumpy' Kanahele and His Aloha First Organization Have Been Toiling Steadily for 20 Years.” Honolulu Star Advertiser, July 7, 2014.

Imada, Adria L. 2008. "The Army Learns to Luau: Imperial Hospitality and Military Photography in Hawai' ${ }^{i}$." The Contemporary Pacific 20 (2): 328-61. https://doi.org/10.1353/cp.0.0001.

James Campbell Company. 2003. James Campbell, Esq. Kapolei, HI: Estate of James Campbell.

Kame'eleihiwa, Lilikala. 1992. Native Land and Foreign Desires: Pehea Lä E Pono Ai? Honolulu: Bishop Museum Press.

Kanahele, Dennis “Bumpy.” 2017. "UNPFII Questionnaire to Indigenous Peoples' Organizations.” Waimanalo: Independent and Sovereign Nation State of Hawai i, 1-23.

-_-. 2018. "Response to 2017 UNPFII Questionnaire to Indigenous Peoples' Organizations.” Pu'ubonua O Waimānalo: Nation of Hawai i, 1-9.

Kēhaulani Kauanui, J. 2008. Hawaiian Blood: Colonialism and the Politics of Sovereignty and Indigeneity. Durham, NC: Duke University Press. https://doi.org/10.1215/9780822391494. 
- - 2018. The Paradoxes of Hawaiian Sovereignty: Land, Sex and the Colonial Politics of State Nationalism. Durham, NC: Duke University Press. https://doi.org/10.1515/9780822371960.

Lili'uokalani, [Lydia Lili‘u Loloku Walania Kamaka'eha]. 1898. Hawaii’s Story by Hawaii’' Queen. Boston: Lee and Shepard. U Penn Digital Library.

Magin, Janus. 2020. "Historic Oceanfront Property on Oahu's North Shore to Be Listed for \$18M.” Pacific Business News, May 27, 2020. https://www.bizjournals.com/pacific/news/2020/05/27/ historic-oceanfront-property-hawaii-listed- $18 \mathrm{~m} . \mathrm{html}$.

Maka'awa'awa, Brandon. 2019a. "How Native Hawaiians Took Internet Access Into Their Own Hands.” Podcast. Episode 88. Building Local Power. https://ilsr.org/hawaii-communitybroadband-blp-episode-88/.

- - . 2019b. “'These Are Our First Roadways:' Internet Access and Self- Determination in Pu'uhonua O Waimanalo.” The Internet Society: Growing the Internet (blog). October 14, 2019. https://www.internetsociety.org/blog/2019/10/these-are-our-first-roadways-internet-access-andself-determination-in-puuhonua-o-waimanalo/.

Marconi Wireless Telegraph and Signal Company Ltd., Plaintiff, vs. Frederick J. Cross, Defendant. 1901 Circuit Court of the First Judicial Circuit, Territory of Hawaii. Correspondence and Papers Concerning the Hawaiian Islands Contract, 1899-1901. Marconi Archive, Bodleian Libraries, University of Oxford (Shelfmark: MS Marconi 179).

McCallum, Kerry, and Franco Papandrea. 2009. "Community Business: The Internet in Remote Australian Indigenous Communities.” New Media E? Society 11 (7): 1230-51. https://doi.org/ $\underline{10.1177 / 1461444809342059}$.

Middleton, Catherine, and Barbara Crow. 2008. "Building Wi-Fi Networks for Communities: Three Canadian Cases." Canadian Journal of Communication 33 (3): 419-41. https://doi.org/10.22230/ cjc.2008v33n3a2110.

Mignolo, Walter. 2010. “The Communal and the Decolonial.” Turbulence: Ideas for Movement, 2010. http://www.turbulence.org.uk/turbulence-5/decolonial/.

- _- 2013. "Geopolitics of Sensing and Knowing: On (De)Coloniality, Border Thinking, and Epistemic Disobedience.” Confero 1 (1): 129-50. https://doi.org/10.3384/ confero.2001-4562.13v1i1129.

Milutis, Joe. 2006. Ether: The Nothing That Connects Everything. Minneapolis: Minnesota University Press.

Nakaso, Dan. 2018. "Waimanalo Land Lease Offers Possible Solution for Waianae Homeless Camp." Honolulu Star Advertiser, February 18, 2018.

Nupepa Kuokoa. 1899. “He Uwea Olelo Ano Hou Loa. Ke Kamahao O Keia Au Hou,” November 10, 1899. Papakilo Database.

Ohnuma, Keiko. 2008. "'Aloha Spirit' and the Cultural Politics of Sentiment as National Belonging.” The Contemporary Pacific 20 (2): 365-94. https://doi.org/10.1353/cp.0.0005.

Oldenziel, Ruth. 2011. "Islands: The United States as a Networked Empire." In Entangled Geographies: Empire and Technopolitics in the Global Cold War, edited by Gabrielle Hecht, 13-41. Cambridge: MIT Press. https://doi.org/10.7551/mitpress/9780262515788.001.0001.

Osorio, Jon Kamakawiwo'ole. 2002. Dismembering Lähui: A History of the Hawaiian Nation to 1887. Honolulu: University of Hawai'i Press. https://doi.org/10.1515/9780824845407.

Pacific Commercial Advertiser. 1899. "Cross's Mission: How Honolulu Promoter Got His Franchise,” November 23, 1899. Chronicling America.

- - . 1900. "Wireless Telegraph Success at Last," November 14, 1900. Chronicling America. 
Parks, Lisa. 2005. Cultures in Orbit: Satellites and the Televisual. Durham, NC: Duke University Press. https://doi.org/10.2307/j.ctv11hpmm4.

Pletts, Vincent J.S. Letter to Major Stephen Flood-Page. n.d. Correspondence and Papers Concerning the Hawaiian Islands Contract, 1899-1901. Marconi Archive, Bodleian Libraries, University of Oxford (Shelfmark: MS Marconi 179).

Pu'uhonua O Waimānalo. n.d. "Hawaiian Cultural Village \& Traditional Lo'i Kalo Agricultural Restoration.” https://www.hawaii-nation.org/puuhonua.html.

Raboy, Marc. 2016. Marconi: The Man Who Networked The World. Oxford: Oxford University Press.

Rosenthal, Gregory. 2018. Beyond Hawaii: Native Labor in the Pacific World. Berkeley: University of California Press. https://doi.org/10.1525/california/9780520295063.001.0001.

Rose-Smith, Imogen. 2020. "Bridging the Digital Divide with Brandon Makawaawaa, Spark Firestarterand Deputy Head of the Sovereign Nation of Hawaii.” Spark Network, July 6, 2020. https://sparknetwork.com/2020/07/06/bridging-the-digital-divide-with-brandon-makaawaawaspark-firestarter-and-deputy-head-of-the-sovereign-nation-of-hawaii/.

Schmitt, Robert. 1978. "Some Transportation and Communication Firsts in Hawaii." Hawaiian Journal of History 12: 99-119.

Sheppard, W. Anthony. 2001. "An Exotic Enemy: Anti-Japanese Musical Propaganda in World War II Hollywood.” Journal of the American Musicological Society 54 (2): 303-57. https://doi.org/ 10.1525/jams.2001.54.2.303.

Siddal, John William. 1997. Men of Hawaii: Being a Biographical Reference Library, Complete and Authentic, of the Men of Note and Substantial Achievement in the Hawaiian Islands. Vol. I. Honolulu: Honolulu Star-Bulletin, Ltd. https://archive.org/details/menofhawaiibiogr00sidd.

Silva, Noenoe K. 2004. Aloba Betrayed: Native Hawaiian Resistance to American Colonialism. Durham, NC: Duke University Press. https://doi.org/10.1215/9780822386223.

Silva, Noenoe K., and Iokepa Badis. 2008. "Early Hawaiian Newspapers and Kanaka Maoli Intellectual History, 1834-1855." The Hawaiian Journal of History 42: 105-34.

Smithies, James. 2008. "The Trans-Tasman Cable, the Australasian Bridgehead and Imperial History." History Compass 6 (3): 691-711. https://doi.org/10.1111/j.1478-0542.2008.00518.x.

Smulyan, Susan. 2007. "Live from Waikiki: Colonialism, Race, and Radio in Hawaii, 1934-1963.” Historical Journal of Film, Radio and Television 27 (1): 63-75. https://doi.org/10.1080/ $\underline{01439680601177148 .}$.

Starosielski, Nicole. 2012. "Warning: Do Not Dig': Negotiating the Visibility of Critical Infrastructures." Journal of Visual Culture 11 (1): 38-57. https://doi.org/10.1177/ 1470412911430465.

Streeter, Thomas. 1996. Selling the Air: A Critique of the Policy of Commercial Broadcasting in the United States. Chicago: University of Chicago Press. https://doi.org/10.7208/chicago/ 9780226777290.001 .0001$.

Sur, Wilma. 2008. "Hawai'i's Masters and Servants Act: Brutal Slavery?” University of Hawai i Law Review 31 (59): 87-112. https://heinonline.org/HOL/P?h=hein.journals/uhawlr31\&i=89.

Teves, Stephanie Nohelani. 2015. “Aloha State Apparatuses.” American Quarterly 67 (3): 705-26. https://doi.org/10.1353/aq.2015.0046.

The Daily Bulletin. 1887. "Points in Hawaiian History,” September 30, 1887. Chronicling America.

The Evening Bulletin. 1898. “F. J. Cross Will Investigate Plantation Possibilities," September 24, 1898. Chronicling America.

_-_. 1899. "Water Will Pump Water,” May 17, 1899. Chronicling America. 
“The Hawaiian Sovereignty Movement: Operating on a False Premise.” 2014. Hawaiian Kingdom $B \log$ (blog). June 14, 2014. https://hawaiiankingdom.org/blog/the-hawaiian-sovereigntymovement-operating-on-a-false-premise/.

Thibault, Gislain. 2014. "Wireless Pasts and Wired Futures." In Theories of the Mobile Internet: Materialities and Imaginaries, edited by Andrew Herman, Jan Hadlow, and Thom Swiss, 87-104. New York: Routledge.

Tully, John. 2009. "A Victorian Ecological Disaster: Imperialism, the Telegraph, and Gutta-Percha." Journal of World History 20 (4): 559-79. https://doi.org/10.1353/jwh.0.0088.

Walker, Janet. 2018. “Media Mapping and Oil Extraction: A Louisiana Story.” NECSUS: European Journal of Media Studies 7 (2): 229-51. https://necsus-ejms.org/media-mapping-and-oilextraction-a-louisiana-story/.

Wilson, Woodrow. 1917. Executive Order 2585-Taking Over Necessary and Closing Unnecessary Radio Stations. The American Presidency Project. https://www.presidency.ucsb.edu/documents/ executive-order-2585-taking-over-necessary-and-closing-unnecessary-radio-stations.

Winseck, Dwayne R., and Robert Pike. 2007. Communication and Empire: Media, Markets, and Globalization, 1860-1930. Durham, NC: Duke University Press. https://doi.org/10.1215/ 9780822389996. 